RESEARCH ARTICLE

\title{
Quality of surface and ground waters for domestic and irrigation purposes in CKD/CKDu prevalent areas in Moneragala District, Sri Lanka
}

\author{
H.M.K.P. Dissanayake ${ }^{1}$, W.A.C. Udeshani ${ }^{2}$, S. Koswatte ${ }^{3}$, K.T. Rathnayake ${ }^{2}$, S.V. Gunatilake , R. Fernando $^{5}$ and \\ S.K. Gunatilake ${ }^{2, *}$
}

${ }^{1}$ Postgraduate Institute of Science, University of Peradeniya, Peradeniya, Sri Lanka.

${ }^{2}$ Faculty of Applied Sciences, Sabaragamuwa University of Sri Lanka, Belihuloya, Sri Lanka.

${ }^{3}$ Faculty of Geomatics, Sabaragamuwa University of Sri Lanka, Belihuloya, Sri Lanka.

${ }^{4}$ Department of Geology, University of Peradeniya, Peradeniy, Sri Lanka.

${ }^{5}$ The Open University of Sri Lanka, Nawala, Nugegoda, Sri Lanka.

Received: 03/06/2019 ; Accepted: 15/01/2020

\begin{abstract}
Total of 152 water samples from $\mathrm{CKD} / \mathrm{CKDu}$ endemic areas and 30 water samples from non-CKDu prevalent areas in the Moneragala District were collected separately. $\mathrm{pH}$ values of water samples varied from 5.04 to 8.37 which are within the permissible limit prescribed by World Health Organization. More than $15 \%$ of water samples showed low Dissolved Oxygen (DO) values indicating heavy contamination by organic matter. Electrical conductivity was high ranging between 32 and 2865 $\mu \mathrm{S} / \mathrm{cm}$ indicating higher mineralization in groundwater. The major ion chemistry reveals that the array of abundance of cations was variable as $\mathrm{Na}^{+}>\mathrm{Ca}^{2+}>\mathrm{Mg}^{2+}>\mathrm{K}^{+}$in dug wells, $\mathrm{Ca}^{2+}>\mathrm{Na}^{+}$ $>\mathrm{Mg}^{2+}>\mathrm{K}^{2+}$ in tube wells and $\mathrm{Ca}^{2+}>\mathrm{Na}^{+}>\mathrm{K}^{+}>\mathrm{Mg}^{2+}$ in surface waters, while anions varied as $\mathrm{HCO}_{3}^{-}>\mathrm{Cl}^{-}>\mathrm{SO}_{4}^{2-}>\mathrm{F}^{-}$in water samples in both seasons. Computed WQI, $43 \%, 33 \%$, and $82 \%$ for dug wells, tube wells and surface water respectively were in good water quality in this area, while waters in $30 \%$ and $25 \%$ of dug and tube wells respectively exceeded the value of 100 showing not suitable category. Considering irrigation quality, $88 \%, 93 \%$ and $96 \%$ of dug, tube and surface waters respectively were less than the permissible level. SAR values in the study area ranged from 0.08 to $4.91 \mathrm{meq} / \mathrm{L}$ by showing no danger of sodium as per SAR. The bulk of studied waters are appropriate for irrigation according to Residual Sodium Carbonate (RSC). Considering KR and PI, majority of water samples of the study area are suitable for irrigation purposes.
\end{abstract}

Keywords: groundwater, surface water, water quality index, irrigation water, $\mathrm{CKDu}$

\section{INTRODUCTION}

In the world community, spreading of chronic diseases has shown a large occurrence. Although Hypertension and Diabetes are known to be the main causes for high prevalence of Chronic Kidney Diseases (CKD), the majority of patients do not show any identifiable causes and it has been named CKD of unknown etiology (CKDu)(Dharma-Wardana et al., 2015). CKDu has been a concern in many countries since the mid-twentieth century including Canada (Arora et al., 2013), United States (Coresh et al., 2007), China (Lin et al., 2014), South-Asia (Jessani et al., 2014) etc. The CKDu found in Sri Lanka is somewhat similar to Balkan Endemic Nephropathy (BEN) recorded in Serbia, Bosnia, Croatia, Bulgaria and Rumania (Batuman, 2006; Stefanović, 1999). It is a slowly progressive chronic tubular-interstitial disease that is present among farmers affecting with a possible environmental nephrotoxin (Batuman, 2006).

Based on observations of past researches, there is a strong evidence that $\mathrm{CKDu}$ has a profound relationship with multi-factorial causes such as cyanobacterial toxins (Madhushankha et al., 2016), ocharatoxins (Wanigasuriya et al., 2008), aristalochic acid (Weaver et al., 2015), poorquality aluminum utensils for cooking purposes and high fluoride drinking water ((Ileperuma et al., 2009), long term exposure to sunlight and dehydration (Siriwardhana et al., 2015) and water ionicity (Dharma-Wardana et al., 2015). Also, it was pointed out that CKDu is attributed to presence of irrigation works and rivers that bring-in fertilizer runoff from intensely agricultural regions (Wimalawansa, 2016). Several studies have shown the potential of correlation of heavy metals such as mercury, chromium, uranium, lead and cadmium (Doul et al., 1980) arsenic, gold, iron, antimony, platinum and thallium (Maher, 1976) and silicon (Saldanha et al., 1975) with CKDu.

Since the reported incidences of $\mathrm{CKDu}$ have increased from several provinces in dry zone in Sri Lanka (Ramachandran, 1994), it has become a major health issue in North Central, Uva, North Western, Central and Northern provinces in Sri Lanka (Gunatilake et al., 2015; Wanigasuriya, 2012). Hence, identifying the causes of $\mathrm{CKDu}$ in order to prevent and treat the disease as well as save vulnerable lives is urgently needed.

Since recently, out of the sources of contamination, agriculture has shown both direct and indirect effects on water quality. The deterioration of the quality of drinking water threatens human health, economic development, and social prosperity (Milovanovic, 2007). The people who are living in $\mathrm{CKD} / \mathrm{CKDu}$ prevalence areas in the country mainly use groundwater and surface water for 
domestic and agricultural purposes. Therefore, quality of surface water and groundwater has received immense attention since water with good quality is required for domestic and irrigation needs. Water supply and drainage board in Moneragala District supplies surface water (reservoir water) and groundwater for domestic purposes after purification in some areas, while using it directly for irrigation practices. Various technologies such as Reverse Osmosis (RO) water, rain water harvesting, etc. are being used in endemic areas for domestic purposes. But feasibility studies need to be conducted to identify low cost technologies for continuing the sustainability. Hence, this study is aimed at understanding the quality of surface and groundwater by developing of a water quality index (WQI) to assess their suitability for domestic purposes. Suitability of water for irrigation purposes was monitored by considering several other irrigation water quality indices in $\mathrm{CKD} / \mathrm{CKDu}$ prevalence areas in Moneragala District in Uva province, Sri Lanka.

\section{Water Quality Index (WQI)}

WQI is an important parameter for demarcating water quality and its suitability for drinking purposes ((Mishra et al., 1985). There are many Water Quality Indices around the world (National Sanitation Foundation Water Quality Index), NSFWQI (Brown et al., 1970), Florida Stream Water Quality Index, FWQI (Environment, 1995), British Columbia Water Quality Index, BCWQI (Zandbergen and Hall, 1998), Oregon Water Quality Index, OWQI (Cude, 2001) and the Canadian Water Quality Index (Khan et al., 2004). For this study, Weighted Arithmetic Water Quality Index method was applied.

\section{Weighted arithmetic water quality index method (WAWQI)}

Weighted arithmetic water quality index method was proposed by Horton ( 1965) and modified by Cude (2001). This method has been widely used by various scientists (Balan et al., 2012; Chauhan and Singh, 2010; Chowdhury et al., 2012) and the calculations were made using the following equations (Brown et al., 1972).

$$
W Q I=\sum_{i=1}^{n} w_{i} q_{i} / \sum_{i=1}^{n} w_{i}
$$

Where $w_{i}$ is the unit weight water quality for the $i^{\text {th }}$ parameter and $q_{i}$ is the quality rating scale of the $i^{\text {th }}$ parameter.

$$
w_{i}=\frac{k}{v_{s}}
$$

$$
\begin{aligned}
& k=\frac{1}{\sum_{i-1}^{n} v_{i}} \\
& q_{i}=\frac{\left(v_{i}-v_{o}\right)}{\left(v_{s}-v_{o}\right)}
\end{aligned}
$$

Where $k$ is the proportionality constant, $v_{i}$ is the estimated concentration of the $i^{\text {th }}$ parameter in the laboratory analysis, $v_{o}$ is the real value of the $i^{\text {th }}$ parameter in pure water $\left(v_{o}\right.$ $=7$ for $\mathrm{pH}$ and 0 for other parameters (Chowdhury et al., 2012), $v_{s}$ is the standard value according to the Sri Lanka Standards (SLS 614:2013). Rating of the water quality according to the WQI is given in the Table 1. This index has already been developed for Jaffna peninsula of Sri Lanka (Harshan et al., 2017). As a further attempt, this study illustrates the developing of the WQI for surface water and groundwater in CKDu prevalence area in Moneragala District in Sri Lanka.

\section{Irrigation water quality}

Sodium Absorption Ration (SAR), Percent Sodium $(\% \mathrm{Na})$, Residual Sodium Carbonate (RSC), Magnesium Hazard (MH), Kelley's Ratio (KR) and Permeability Index (PI) were calculated using the following Equations 5, 6 (Richards 1969), Equation 7 (Todd 1980), Equation 8 (Kelly, 1963) and Equation 9 (Doneen, 1962) to monitor the irrigation water quality.

$$
\begin{aligned}
& \mathrm{SAR}=\left[\mathrm{Na}^{+}\right] / \sqrt{\left\{\left[\mathrm{Ca}^{2+}\right]+\left[\mathrm{Mg}^{2+}\right]\right\} / 2} \\
& \% \mathrm{Na}=\frac{\left\{\left[\mathrm{Na}^{+}\right]+\left[\mathrm{K}^{+}\right]\right\} \times 100}{\left\{\left[\mathrm{Ca}^{2+}\right]+\left[\mathrm{Mg}^{2+}\right]+\left[\mathrm{Na}^{+}\right]+\left[\mathrm{K}^{+}\right]\right\}}
\end{aligned}
$$

$$
\begin{aligned}
& \text { Magnesium Hazard }(\mathrm{MH})=\frac{\left[\mathrm{Mg}^{2+}\right] \mathrm{X} 100}{\left[\mathrm{Ca}^{2+}\right]+\left[\mathrm{Mg}^{2+}\right]} \\
& \text { Kelley's Ratio }=\frac{\mathrm{Na}^{+}}{\mathrm{Ca}^{2+}+\mathrm{Mg}^{2+}}
\end{aligned}
$$

Permeability Index $=\frac{\left(\mathrm{Na}^{+}+\sqrt{\mathrm{HCO}_{3}^{-}}\right) * 100}{\left(\mathrm{Ca}^{2+}+\mathrm{Mg}^{2+}+\mathrm{Na}^{+}\right)}$

where all cationic concentrations are expressed in meq/L.

\section{Study Area}

Moneragala District in Uva Province lies between the northern latitudes 6.17" and 7.2.8" and eastern longitudes $80.50 "$ and 81.35 ". This district is divided into 9 Assistant Government Agent divisions, namely

Table 1: Water quality rating as per the weight arithmetic water quality index method.

\begin{tabular}{ll}
\hline WQI value & Rating of water quality \\
\hline $0-25$ & Excellent water quality \\
$26-50$ & Good water quality \\
$51-75$ & Poor water quality \\
$76-100$ & Very poor water quality \\
$>100$ & Unsuitable for drinking purposes \\
\hline
\end{tabular}


Bibile, Medagama, Madulla, Badalkubura, Moneragala, Siyabalanduwa, Buttala, Tanamalwila and Wellawaya. Topographically Moneragala district is in a transitional zone from central highlands to flat lowlands. According to the landscape, three terrain types could be identified as highly mountainous terrain, hilly, steep and rolling terrain and undulating and flat terrain with elevation between 550 to $1400 \mathrm{~m}, 160$ to $550 \mathrm{~m}$ and below $150 \mathrm{~m}$ respectively (Cooray, 1967). There are seven river basins which drain crossing Moneragala district. These rivers originate in the west central high lands, flow towards east, south-east and south. Several drainage basins (Hedaoya, Walawe, Kirindi oya, Kiribban oya, Wila oya, Manik ganga, Malala oya) cover approximately $80 \%$ of the land area of the district. Fluctuation levels and volumes of these river basins depend on the seasonal rains.

Quantity of rain received over the nothern and eastern parts of the country during the north-east monsoon is less than the amount received over south-west during the southwest monsoon. The dry zone environment of Moneragala is basically determined by the seasonal spell of rains, resulting in two seasons namely Maha and Yala (Rubasinghe et al., 2015). Total rainfall of the district ranges between 1328$1821 \mathrm{~mm}$ in a year. Over $84 \%$ of rain is received during the seven rainy months from October to January and from March to May. Corresponding to these long and short rainy seasons, there are long and short dry seasons (JuneSeptember and February respectively). The low rainfall during these periods and reduction of rainfall in the upper catchment areas result in frequent drought conditions in a major part of the irrigated area in Moneragala District.

\section{METHODOLOGY}

Regional Directors Health Services Office (RDHSO) in Moneragala district has identified more than $677 \mathrm{CKD} /$ CKDu cases by 2017. Out of them, purposive households were visited and water samples were collected directly from their drinking water sources covering two seasons in 2017. Water samples were collected from dug wells, tube wells and surface water bodies (rivers, reservoirs etc). All samples were properly numbered and a survey was conducted while sampling to get all information about cultivation as well as the patients details (age, occupation, income, clinical states including smoking, diabetes, hypertension etc.).

A total of 182 water samples (101 dug wells, 60 tube wells and 21 surface water from reservoirs and rivers) were collected covering both seasons from the district (Figure 1). A total of 103 samples (67 dug wells, 19 tube wells, 17

Table 2: Standard methods used in chemical analysis.

\begin{tabular}{ll}
\hline Water quality parameter & Standard analytical method \\
\hline Alkalinity & $\mathrm{H}_{2} \mathrm{SO}_{4}$ titrimetric method \\
Total hardness $(\mathrm{TH}), \mathrm{Cl}^{-}$ & titrimetric methods \\
$\mathrm{SO}_{4}^{2-}, \mathrm{F}^{-}, \mathrm{NO}_{3}^{-}, \mathrm{PO}_{4}^{3-}$ & $\mathrm{HACH}$ DR 2700 spectrophotometer \\
$\mathrm{Na}^{+}, \mathrm{K}^{+}, \mathrm{Ca}^{2+}, \mathrm{Mg}^{2+}$ & Inductive Couple Plasma - Mass Spectroscopy \\
& (ICP-MS). \\
\hline
\end{tabular}

The $\mathrm{HCO}_{3}^{-}$and $\mathrm{CO}_{3}{ }^{2-}$ were calculated using alkalinity and $\mathrm{pH}$ values.

Figure 1: Location map of the study area.

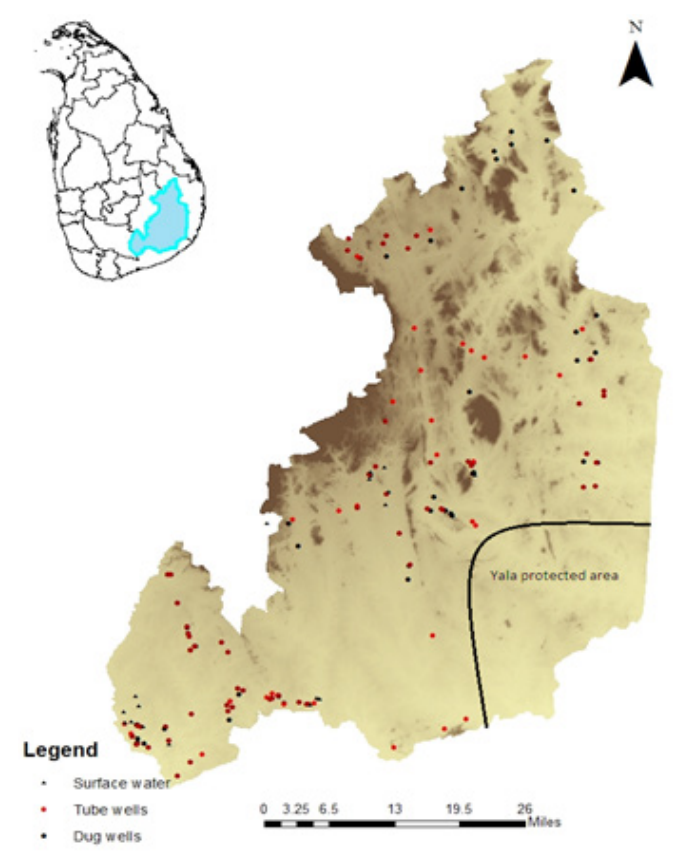


surface water samples) were selected from drinking water sources of CKD/CKDu patients and 49 nonpatients' well water samples (23 dug wells, 22 tube wells and 4 surface samples) were collected from $\mathrm{CKD} / \mathrm{CKDu}$ endemic areas in the district. Other 30 water samples (11 dug wells and 19 tube wells) were collected from non-prevalent areas in the district. Water samples were collected into high-density polyethylene bottles which were acid soaked overnight and then washed thoroughly with distilled water. Two subsets of samples were also collected for laboratory analysis. One set of samples was filtered and acidified by adding several drops of ultra-pure nitric acid for cation analysis, while the un-acidified sample set was used for anion analyses (Table 2). $\mathrm{pH}, \mathrm{EC}$, temperature, oxidation-reduction potential (ORP) were measured in situ using pre-calibrated Hach Sension $\mathrm{pH} / \mathrm{EC}$ Multiparameter. All collected samples were kept cooled at $4^{\circ} \mathrm{C}$ until the analyses were performed.

\section{RESULTS AND DISCUSSION}

According to the data collected from RDHSO, a total of $677 \mathrm{CKD} / \mathrm{CKDu}$ patients have been identified in 2017 from different areas in Monaragala district (Figure 2). According to the Figure 2, the highest number of $\mathrm{CKD} /$
CKDu patients (167) was recorded from both Thanamalwila and Sewanagala DS divisions, while 114 patients recorded from Siyabalanduwa DS division. Comparatively other DS divisions of Thanamalwila, Sewanagala and Siyabalanduwa areas show the highest prevalence of $\mathrm{CKD} / \mathrm{CKDu}$ patients in Monaragala district. At a glance, northern part of the Monaragala District shows lesser number of CKD/CKDu patients, whereas more patients are reported in southern and southwestern parts of Monaragala District.

Based on the recorded data, total of 116 patients were interviewed during the site visits. High blood pressure and diabetics were identified as main causes for CKD. The patients who are not attributed to diabetes, hypertension or other known aetiologies were categorized as CKDu. Survey results revealed that $31.9 \%$ of CKD patients belonged to CKDu group (Figure 3 a). Among those CKDu patients, highest number of patients was recorded from Thanamalwila and Sewanagala areas respectively (Figure 3b).

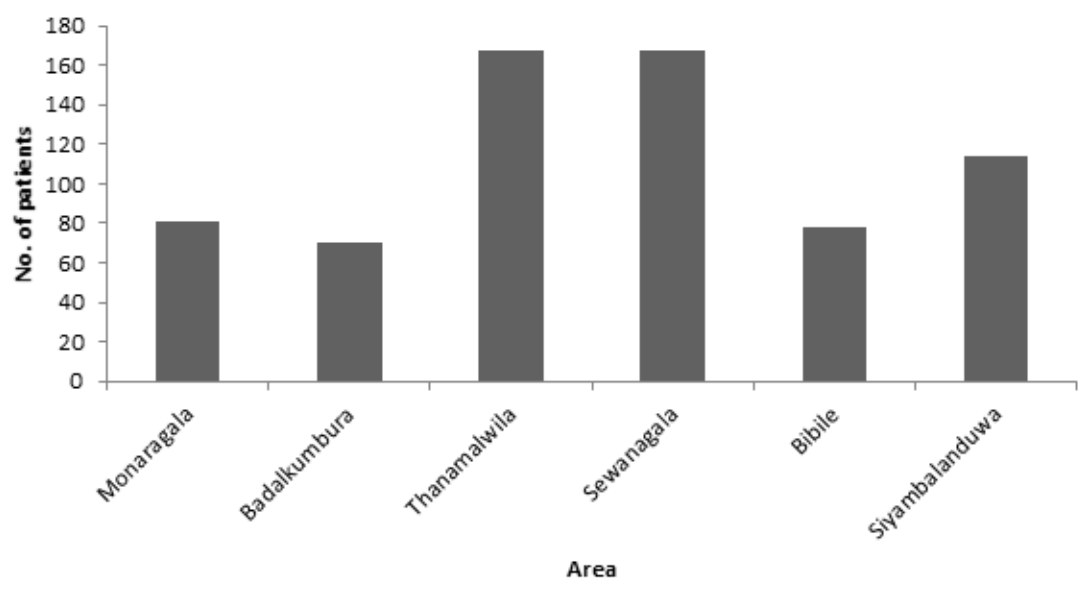

Figure 2: Number of CKD/CKDu patients identified by 2016.
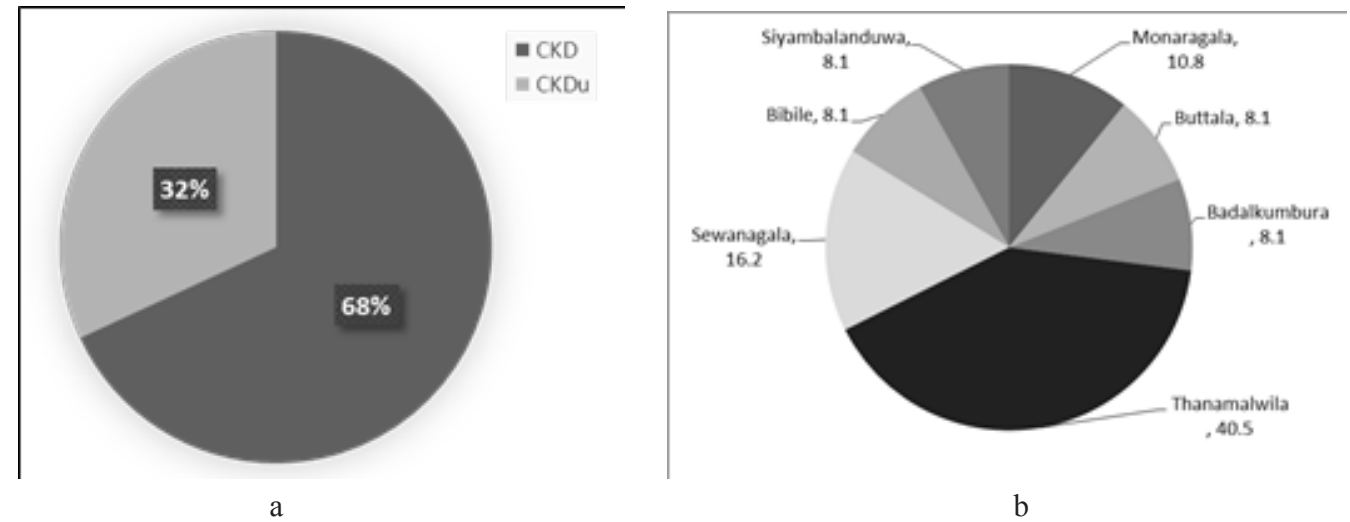

Figure 3: Recorded CKD and CKDu patients (a) and prevalence of CKDu patients in each DS division (b) during the study. 


\section{Groundwater quality for drinking purposes}

The compositions of surface and groundwater in the study area are summarized in Table 3. The availability of drinking water is an essential requirement of humans as stipulated by international law and the declarations (Kausar et al. 2011). In drinking water, $\mathrm{pH}$ is one of the most significant quality parameters which may affect health of humans (Rahmanian et al. 2015).

$\mathrm{pH}$ values below 4 produce a sour taste and higher values above 8.5 give an alkaline taste (Trivedy et al., 1986). In the present study, the $\mathrm{pH}$ values of water samples varied from 5.04-8.37 in dug wells, 5.61-8.16 in tube wells and 5.77-8.01 in surface water showing that all samples are within the limit prescribed by WHO, 2003. Dissolved oxygen (DO) reflects the physical and biological processes prevailing in water and indicates the degree of pollution in water bodies. In this region, more than $15 \%$ of water samples (groundwater and surface water) showed low DO values (DO less than 5.00) indicating heavy contamination by organic matter. Electrical conductivity (Reddad et al., 2002)is found to be very high ranging between 32 and 2865 $\mu \mathrm{S} / \mathrm{cm}$ in dug wells and $69-1823 \mu \mathrm{S} / \mathrm{cm}$ in tube wells when compared to that of surface water (average value $-321 \mu \mathrm{S}$ / $\mathrm{cm})$. This indicate higher mineralization of groundwater (Rubasinghe et al., 2015). Only $11 \%$ of dug wells and 19\% of tube wells water exceeded the permissible level of EC, i.e., $1500 \mu \mathrm{S} / \mathrm{cm}$ (WHO and Organization, 2003).

Considering the Figure 4, it can be clearly observed that most of the samples exceed the desirable limit of $300 \mathrm{mg} / \mathrm{L}$ (WHO and Organization, 2003) for total hardness. Higher $\mathrm{SO}_{4}^{2-}$ ions in groundwater samples (average $37 \mathrm{mg} / \mathrm{L}$ in dug wells and $36.7 \mathrm{mg} / \mathrm{L}$ in tube wells) indicate the occurrence of permanent hardness in aquifers of this region.

Almost $50 \%$ of dug well water, $42 \%$ of tube well water and all surface water bodies in the area showed less than permissible level of TDS according to the WHO guidelines

Figure 4: The relationship between EC and Total Hardness.

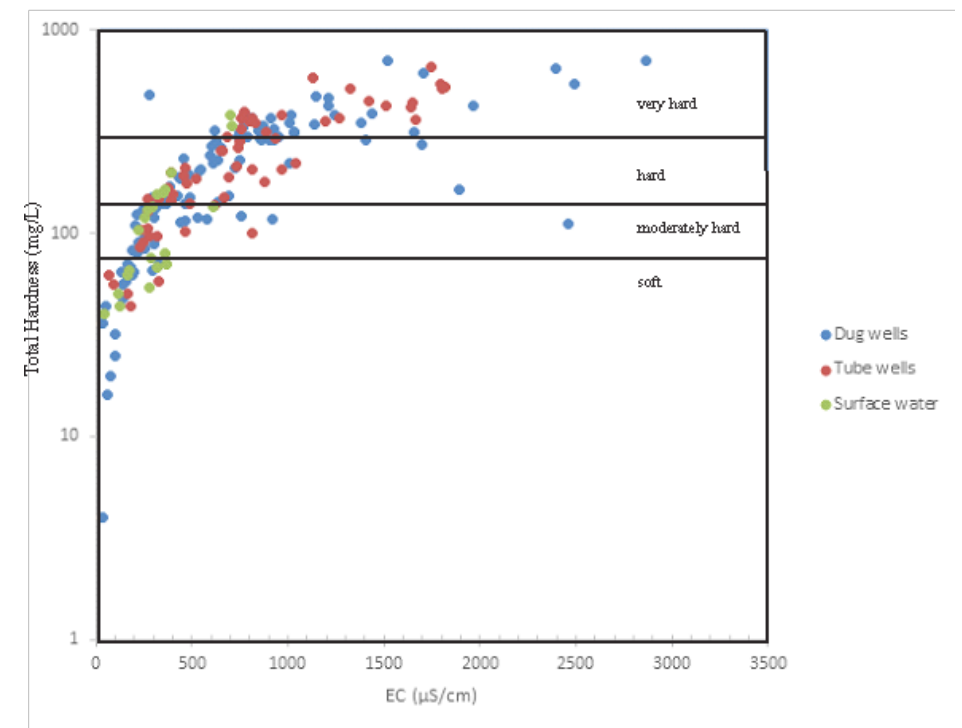

Table 3: The compositions of physico-chemical parameters in groundwater and surface water.

\begin{tabular}{|c|c|c|c|c|c|c|c|c|c|c|c|c|c|c|c|}
\hline 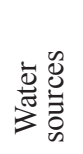 & 폴 & 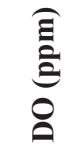 & 象言 & $\underset{\substack{0 \\
ٍ}}{\overparen{E}}$ & 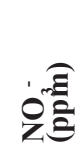 & 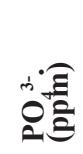 & $\stackrel{\dot{1}}{\mathrm{O}^{+}} \widehat{\widehat{\Xi}}$ & 彦 & 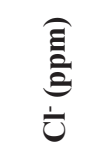 & 导言 & 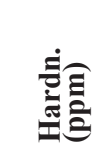 & $\tilde{Z}$ & $\sum^{\infty}$ & 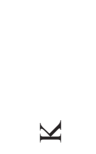 & $\pi$ \\
\hline \multicolumn{16}{|c|}{ Dug wells } \\
\hline Min & 5.04 & 1.88 & 28.27 & 32.16 & 1.33 & 0.02 & 2.00 & 0.02 & 11.00 & 12.0 & 4.000 & 4.07 & 0.57 & 0.29 & 1.46 \\
\hline Max & 8.37 & 21.4 & 4523 & 2865 & 11.5 & 4.86 & 540 & 2.93 & 1100 & 738 & 1464 & 425 & 56.6 & 7.28 & 128 \\
\hline Ave & 7.07 & 8.34 & 650.8 & 704.9 & 2.70 & 0.46 & 37.1 & 1.00 & 65.61 & 262 & 232.4 & 46.1 & 10.9 & 1.39 & 42.1 \\
\hline \multicolumn{16}{|c|}{ Tube wells } \\
\hline Min & 5.61 & 1.62 & 61.23 & 69.68 & 1.33 & 0.04 & 2.00 & 0.10 & 13.0 & 42 & 44 & 4.70 & 2.526 & 0.55 & 11.10 \\
\hline Max & 8.16 & 28.4 & 1610 & 1823 & 7.97 & 1.24 & 190 & 5.65 & 301 & 518 & 660 & 164.5 & 52.28 & 7.41 & 206.2 \\
\hline Ave & 7.15 & 7.49 & 669.4 & 765.3 & 2.53 & 0.27 & 35.7 & 1.11 & 61.1 & 270 & 253 & 51.64 & 16.02 & 2.06 & 58.40 \\
\hline \multicolumn{16}{|c|}{ Surface Water } \\
\hline Min & 5.77 & 3.24 & 38.50 & 42.91 & 0.3 & 0.03 & 2.0 & 0.05 & 8.00 & 20.0 & 40.0 & 5.541 & 0.28 & 0.460 & 10.24 \\
\hline Max & 8.01 & 23.4 & 636.8 & 710.3 & 3.6 & 0.82 & 28 & 1.06 & 41.0 & 330 & 382 & 39.30 & 2.90 & 56.57 & 64.88 \\
\hline Ave & 7.27 & 9.39 & 244.0 & 320.6 & 0.8 & 0.25 & 8.0 & 0.36 & 19.5 & 119 & 125 & 15.23 & 2.26 & 13.84 & 27.18 \\
\hline
\end{tabular}


(WHO and Organization, 2003). High TDS water may be due to the high evaporation process, low rainfall and high ambient temperature in the region. Total alkalinity of 52\% in dug wells, $62 \%$ intube wells and $9.5 \%$ in surface water bodies exceed the permissible level of $200 \mathrm{ppm}$ due to , and $\mathrm{OH}^{-}$compounds; and - in top soil layer (Garg et al., 2008).

These results show that fluoride levels in water consumed by $\mathrm{CKD} / \mathrm{CKD}$ patients in affected areas vary from 0.02 to $2.93 \mathrm{mg} / \mathrm{L}$ in dug wells, $0.10-5.65 \mathrm{mg} / \mathrm{L}$ in tube wells and $0.05-1.06 \mathrm{mg} / \mathrm{L}$ in surface water bodies. Out of the studies samples, $60 \%$ of the dug well samples, $73 \%$ of tube well samples and $19 \%$ of surface water samples are above the limit $(0.5 \mathrm{mg} / \mathrm{L})$ recommended for tropical countries by the WHO (Chandrajith et al., 2011). Therefore, it is apparent that people in $\mathrm{CKD} / \mathrm{CKDu}$ affected areas in the district are already being contaminated with high amounts of fluoride (Dharmagunwardane and Dissanayake, 1993).

The $\mathrm{Cl}^{-}$content was found to vary between 11 and 1100 $\mathrm{mg} / \mathrm{L}$ in dug wells, $13-301 \mathrm{mg} / \mathrm{L}$ in tube wells and 8.0-40 $\mathrm{mg} / \mathrm{L}$ in surface water in $\mathrm{CKD} / \mathrm{CKDu}$ areas. Chloride in all samples collected from non-prevalent areas showed less than the permissible level $(250 \mathrm{mg} / \mathrm{L})$ prescribed by WHO, 2003. The major ion chemistry reveals that the array of abundance of cations was serried as $\mathrm{Na}^{+} .>\mathrm{Ca}^{2+} .>\mathrm{Mg}^{2+}>\mathrm{K}^{+}$ in dug wells, $\mathrm{Ca}^{2+}>\mathrm{Na}^{+}>\mathrm{Mg}^{2+}>\mathrm{K}^{+}$in tube wells and $\mathrm{Ca}^{2+}>$ $\mathrm{Na}^{+}>\mathrm{K}^{+}>\mathrm{Mg}^{2+}$ in surface waters. The abundance order of anions varied as $\mathrm{HCO}_{3}^{-}>\mathrm{Cl}^{-}>\mathrm{SO}_{4}{ }^{2-}>\mathrm{F}^{-}$in all groundwater samples and surface water samples in both seasons.

\section{Calculation of WQI}

For the calculation of WQI, twelve important parameters are considered $(\mathrm{pH}$, Total Alkalinity, Total Hardness, Chloride, Sulfate, Nitrate, Phosphate, Fluoride, Calcium, Sodium, Potassium, and Magnesium). The WQI calculates by using water quality standards. In this study, the computed WQI values range from 0.54 to 338.04 Considering WQI, overall in almost $43 \%$ of the dug wells, water samples are of good water quality in this area and $30 \%$ of the samples exceeded the WQI value of 100 showing the water is not suitable for drinking purposes. The high value of WQI can be attributed mainly to the higher values of fluoride. WQI of tube wells water show that $33.33 \%$ of samples are good quality for drinking and domestic purposes while $42 \%$ of water samples falls into poor drinking water quality category. Only 25\% of water sample exceeds WQI of 100. Eighty two percent of the surface water samples fall in good water category and the rest of the samples are in poor water category. None of the surface water samples exceeded the maximum value of WQI 100.

\section{Suitability of water for irrigation purposes}

The groundwater, river and tank water of the study area are used for irrigation purposes. Water used for irrigation always contains measurable quantities of dissolved substances (salts). Salts usually contain small amounts of dissolved solids originating from dissolution or weathering of the rocks. The main soluble constituents are $\mathrm{Ca}^{2+}, \mathrm{Mg}^{2+}, \mathrm{Na}^{+}$as cations and $\mathrm{Cl}^{-}, \mathrm{SO}_{4}^{2-}$ and $\mathrm{HCO}_{3}^{-}$ as anions. The various salts present in the irrigation water affect plant growth, soil structure and permeability (Mohan et al. 2000).

Crops are very sensitive to $\mathrm{pH}$ of the irrigating water. The best range of $\mathrm{pH}$ for irrigation is between 6.5 and 8.4 (Bauder et al., 2010) indicating all studied samples are suitable for irrigation purpose (Table 4). The total concentration of soluble salts in irrigation water can be classified into low (C1), medium (C2), high (C3) and very high (C4) salinity zones and the values are shown in the Table 3. Higher EC in water creates a saline soil.

The amount of sodium in irrigation water is referred to as $\mathrm{Na} \%$. The $\mathrm{Na}$ content of water reacts with the soil and accumulates in the pore spaces thus reducing its permeability (Khan and Abbasi, 2013). Deterioration of soil structure, poor infiltration, and low aeration are caused due to high $\mathrm{Na} \%(>60 \%)$ in agriculture water supply.

Table 4: Suitability of water for irrigation purposes according to salinity.

\begin{tabular}{lllll}
\hline TDS(ppm) & EC(uS/cm) & Salinity class & $\begin{array}{l}\text { Necessary management } \\
\text { use in irrigation }\end{array}$ & $\begin{array}{l}\text { Representing percentage, } \\
\text { \% }\end{array}$ \\
\hline$<150$ & $<250$ & Excellent $(\mathrm{C} 1)$ & & Dw-22 \\
& & & Tw-12 \\
& & & Sw-29 \\
\hline $150-500$ & $250-750$ & Good $(\mathrm{C} 2)$ & Dw-39 \\
& & & Tw-42 \\
\hline $500-1500$ & $750-2250$ & Permissible $(\mathrm{C} 3)$ & Sw-71 \\
\hline $1500-3000$ & & & Dw-35 \\
& & & Tw-47 \\
& & & Sw-nil \\
\hline & & Unsuitable $(\mathrm{C} 4)$ & Dw-4 \\
& & & Tw-nil \\
& & & Sw-nil \\
\hline
\end{tabular}


According to $\mathrm{Na} \%, 88 \%$ of dug wells, $93 \%$ of tube wells and $96 \%$ of surface water are less than the permissible level of 60 (Table 5).

Plot of Electrical conductivity verses $\mathrm{Na} \%$ is important to evaluate the suitability of water for irrigation purpose (Khan and Abbasi, 2013; Khodapanah et al., 2009). The binary plot consists of five distinct agriculture water quality fields (Figure 5). Adopting this scheme, studied samples are found in permissible to excellent range while few are unsuitable for irrigation purposes.

The SAR is an important parameter for the determination of the suitability of irrigation water because it is responsible for the sodium hazard
(Todd, 1980). High concentration of cations is mainly responsible for sodium or alkali hazard in irrigation water (Ogunfowokan et al., 2013; Gholami and Srikantaswamy, 2009). Low SAR values are always desirable (Raihan and Alam, 2008) because it influences in filtration rate of water. The water of the study area was classified with respect to SAR values (Table 6). According to the above classification, the SAR values in the study area range from 0.08 to $4.91 \mathrm{meq} / \mathrm{L}$ and the samples of the study area cause no danger of sodium consideration in soil according to the SAR values.

Hazard of and on the quality of agricultural water is determined as Residual sodium carbonate (RSC) (Khan and

Table 5: Suitability of water for irrigation purposes according to $\mathrm{Na} \%$.

\begin{tabular}{lllll}
\hline Na\% & Suitability for irrigation & Dug wells, $\%$ & Tube wells, $\%$ & Surface water, $\%$ \\
\hline$<20$ & Excellent & 22 & 16 & 29 \\
$20-40$ & Good & 44 & 45 & 62 \\
$40-60$ & Permissible & 22 & 32 & 5 \\
$60-80$ & Doubtful & 11 & 7 & 4 \\
$>80$ & Unsuitable & 2 & Nil & Nil \\
\hline
\end{tabular}

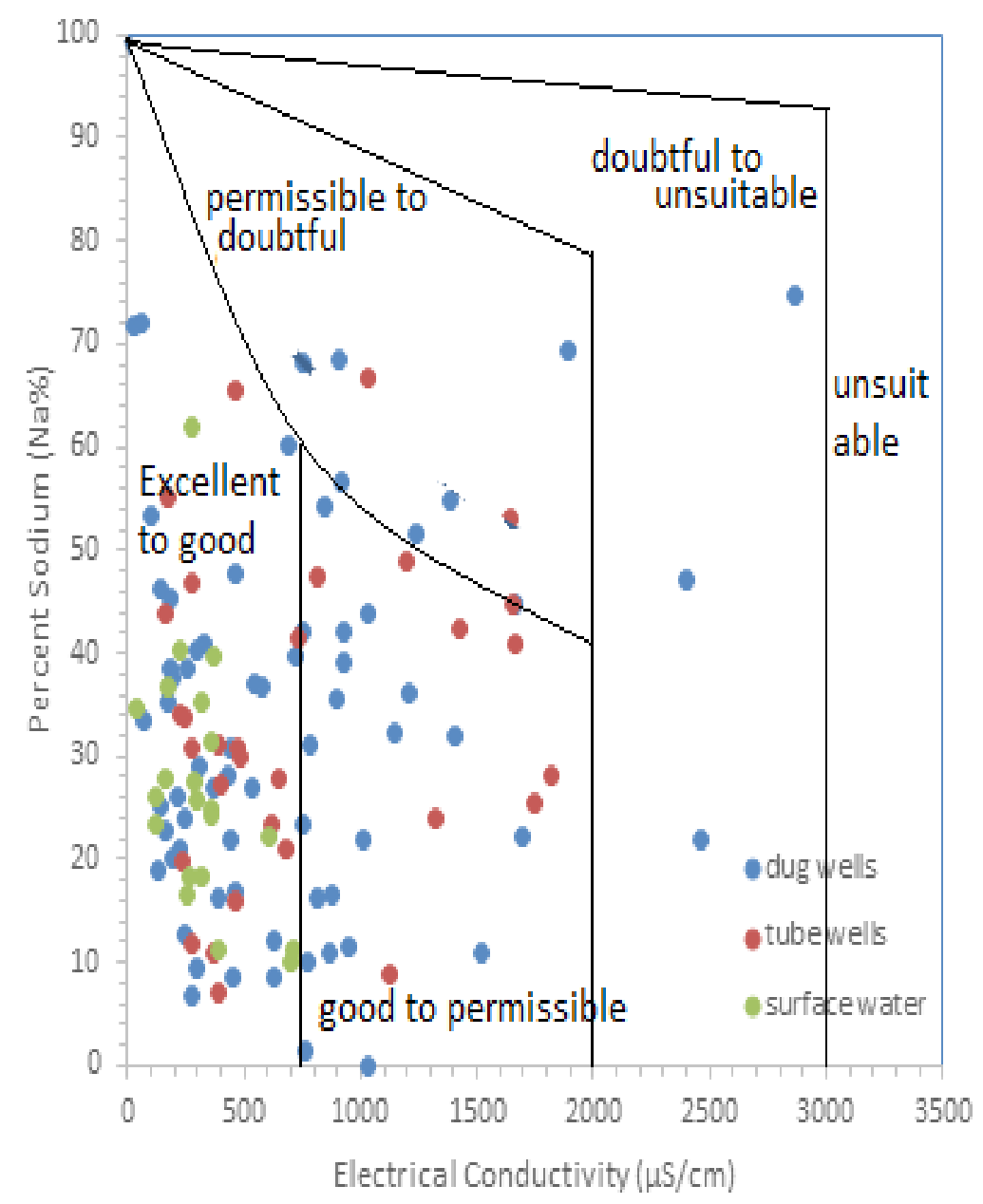

Figure 5: The salinity zones according to EC vs $\mathrm{Na} \%$. 
Table 6: Suitability of water for irrigation purposes according to SAR.

\begin{tabular}{llccc}
\hline SAR\% & Suitability for irrigation & Dug wells, \% & Tube wells, \% & Surface water, \% \\
\hline$<10$ & Excellent & 100 & 100 & 100 \\
$10-18$ & Good & & & \\
$18-26$ & Doubtful & & & \\
$>26$ & Unsuitable & & & \\
\hline
\end{tabular}

Table 7: Suitability of water for irrigation purposes according to RSC (Camberato, 2001).

\begin{tabular}{llccc}
\hline RSC & Suitability for irrigation & Dug wells, $\%$ & Tube wells, $\%$ & Surface water, \% \\
\hline$<1.25$ & Safe & 49 & 52 & 100 \\
$1.25<$ RSC $<2.5$ & Moderate & 23 & 19 & \\
$>2.5$ & Unsuitable & 28 & 29 & \\
\hline
\end{tabular}

Abbasi, 2013). According to Aghazadeh and Mogaddam (2010), high RSC restricts the movement of water and air in soil. According to RSC values, irrigation water is classified into three classes: safe, moderate, and unsuitable (Camberato, 2001). Data in Table 7 show that bulk of the studied waters are appropriate for irrigation (RSC < $2.5 \mathrm{meq} / \mathrm{L}$ ). Only $28 \%$ of dug wells and $29 \%$ of tube wells waters are considered unsuitable and harmful for irrigation.

The $\mathrm{MH}$ is also one of the important factors to evaluate quality of irrigation water. Gupta and Gupta (1987) mentioned that high $\mathrm{MH}$ affects the soil unfavorably, a harmful effect on soils appears when $\mathrm{MH}$ exceeds 50 the permissible limit of irrigation quality standards. In the present study, $28 \%, 18 \%$ and $20 \%$ of dug wells, tube wells and surface water sources respectively exceed the value 50 which may cause harm to soil. Therefore, it can be concluded that groundwater in most of the study area is found to be suitable for irrigation.

Kelly (1963) described the ratio of $\mathrm{Na} /(\mathrm{Ca}+\mathrm{Mg})$ which evaluates the suitability of water for irrigation purposes. Kelley's ratio (KR) should not exceed 1 for irrigation water (Kelly, 1963). Among dug and tube wells, 75\% and 85\% samples have KR values $<1$ respectively, while $95 \%$ of surface water samples $(\mathrm{KR}<1)$ are suitable for irrigational uses. Rest of water samples has KR values $\geq 1$.

The PI is employed to assess quality of irrigation water. Soil permeability is reduced by the consecutive use of water-containing high salts (Singh and Singh, 2008). According to the classification of PI, irrigation water with high permeability $(>75 \%)$ is classified as Class I, while Class II has permeability between $75 \%$ and $50 \%$ (Nagaraju et al., 2006). Class I and Class II waters are categorized as good for irrigation purposes. The third category (Class III) is unsuitable with $25 \%$ of maximum permeability (Dhirendra et al., 2009). On the basis of the PI classification, majority of water samples of the study area belong to classes I and II (91\% dug and tube wells in Class I and 9\% in Class II) and suitable for irrigation purposes.

\section{CONCLUSIONS}

Geochemical studies of groundwater and surface water in $\mathrm{CKD} / \mathrm{CKDu}$ endemic areas in Moneragala District display a trend of ionic abundances of $\mathrm{Na}^{+}>\mathrm{Ca}^{2+}>$ $\mathrm{Mg}^{2+}>\mathrm{K}^{+}$in dug wells, $\mathrm{Ca}^{2+}>\mathrm{Na}^{+}>\mathrm{Mg}^{2+}>\mathrm{K}^{+}$in tube wells and $\mathrm{Ca}^{2+}>\mathrm{Na}^{+}>\mathrm{K}^{+}>\mathrm{Mg}^{2+}$ in surface waters and $\mathrm{HCO}_{3}>\mathrm{Cl}^{-}>\mathrm{SO}_{4}{ }^{2-}>\mathrm{F}^{-}$abundance trend of anions for both cultivation seasons (Yala and Maha). High range of EC $(10 \%)$, TDS (42\%), TH (47\%) and $(18 \%)$ may be due to high evaporation, mineralization and low rainfall. $76.5 \%$ of fluoride concentration of the groundwater samples exceeds the WHO permissible limit for tropical countries indicating direct impact of underground geology of the area to groundwater. Computed WQI varied between 0.53338. Almost 39 and $33 \%$ of groundwater samples are in good and poor water category respectively while $28 \%$ groundwater samples are not suitable for domestic purposes according to WQI. The WQI values are very high in CKDu prevalence area showing the drinking water quality has direct impact with CKDu. It identifies that fluoride is the main parameter for changing WQI in the study area, with comparing other parameters. Also this study revealed that the communities who depend on dug wells which are in close proximity to the developed irrigation systems used for agriculture with seepage to the wells are more affected by CKDu compared to the other communities in the region. Therefore, treatments are essential before the consumption of groundwater for drinking purposes especially in $\mathrm{CKDu}$ prevalence area in Monaragala District. However, this study showed that reservoirs, small tanks and river waters are more suitable for domestic purposes. More than $88 \%$ of ground and surface water samples are less than the permissible level prescribed for $\mathrm{Na}$. EC, SAR, $\mathrm{Na} \%$, $\mathrm{RSC}, \mathrm{MH}, \mathrm{KR}$, and PI values show that a majority of the water samples from ground and surface water are fit for irrigation purpose except for a few samples. Poor water quality water due to high fluoride is mainly found in $\mathrm{CKDu}$ patients' wells in $\mathrm{CKD} / \mathrm{CKDu}$ endemic areas. Also this study reveals that WQI can provide an excellent way as an easy interpretation indicator to detect changes in water quality.

\section{ACKNOWLEDGEMENT}

Financial support received by the Sabaragamuwa University of Sri Lanka under the Grant Number SUSL/ $\mathrm{RG} / 2016 / 13$ is highly appreciated. 


\section{DECLARATION OF CONFLICT OF INTEREST}

The Authors declare that there is no conflict of interest.

\section{REFERENCES}

Aghazadeh, N. and Mogaddam, A.A. (2010). Assessment of groundwater quality and its suitability for drinking and agricultural uses in the Oshnavieh Area, Northwest of Iran. Journal of Environmental Protestation 1:30-40, DOI:10.4236/jep.2010.11005.

Arora, P., Vasa, P., Brenner, D., Iglar, K., McFarlane, P., Morrison, H. and Badawi, A. (2013). Prevalence estimates of chronic kidney disease in Canada: results of a nationally representative survey. Canadian Medical Association Journal 185(9) E: 417-423 , DOI: 10.1503/ cmaj.120833.

Balan, I., Shivakumar, M. and Kumar, P.M. (2012). An assessment of groundwater quality using water quality index in Chennai, Tamil Nadu, India. Chronicles of young scientists. 3: 146-150, DOI: 10.4103/22295186.98688

Batuman, V. (2006). Fifty years of Balkan endemic nephropathy: daunting questions, elusive answers. Kidney international. 69: 644-646, DOI: https://doi. org/10.1038/sj.ki.5000231.

Bauder, T.A, Waskom, R.M. and Davis, J.G. (2010). Irrigation water quality criteria, Colorado State University Extension, Fact Sheet No. 0.506, 7/03. Revised 10/14.

Brown, R.M., McClelland, N.I., Deininger, R.A. and O’Connor, M. F. (1972). A water quality

index-crashing the psychological barrier. Indicators of environmental quality, 173-182, DOI:https://doi. org/10.1007/978-1-4684-2856-8_15.

Brown, R.M., McClelland, N.I., Deininger, R.A. and Tozer, R.G. (1970). A water quality index-do we dare?, Water Sewage Works, 117: 339-343.

Chandrajith, R., Nanayakkara, S., Itai, K., Aturaliya, T., Dissanayake, C., Abeysekera, T., Harada, K., Watanabe, T. and Koizumi, A. (2011). Chronic kidney diseases of uncertain etiology (CKDue) in Sri Lanka: geographic distribution and environmental implications. Environmental geochemistry and health. 33: 267-278, DOI:https://doi.org/10.1007/s10653-010-9339-1.

Chauhan, A. and Singh, S. (2010). Evaluation of Ganga water for drinking purpose by water quality index at Rishikesh, Uttarakhand, India. Report and Opinion. 2: 53-61.

Chowdhury, R.M., Muntasir, S.Y. and Hossain, M.M. (2012). Water quality index of water bodies along Faridpur-Barisal road in Bangladesh. Global Engineers and Technologists Review. 2: 1-8.

Camberato J. (2001) . Irrigation water quality. Turfgrass Program, Clemson University; (Update from the 2001 Carolinas GCSA Annual Meeting).

Cooray, P. (1967). An Introduction to the Geology of Ceylon, National Museums of Ceylon Publication, Colombo. 298 Sarath Jayatileke, 83-141.

Coresh, J., Selvin, E., Stevens, L.A., Manzi, J., Kusek, J.W., Eggers, P., Van Lente, F. and Levey, A.S. (2007). Prevalence of chronic kidney disease in the
United States. Jama. 298: 2038-2047, DOI:10.1001/ jama.298.17.2038.

Cude, C.G. (2001). Oregon water quality index a tool for evaluating water quality management effectiveness. JAWRA Journal of the American Water Resources Association. 37:125-137, DOI: https://doi. org/10.1111/j.1752-1688.2001.tb05480.x.

Dharma-Wardana, M., Amarasiri, S. L., Dharmawardene, N. and Panabokke, C. (2015). Chronic kidney disease of unknown aetiology and ground-water ionicity: study based on Sri Lanka. Environmental geochemistry and health. 37:221-231, DOI :https://doi.org/10.1007/ s10653-014-9641-4.

Dharmagunawardhane, H.A., and Dissanayake, C.B. (1993). Fluoride problems in Sri Lanka. Environmental Management and Health 4: 9-16, DOI: https://oi. org/10.1108/09566169310033422.

Dhirendra, M.J., Kumar, A., and Agrawal, N. (2009). Assessment of the irrigation water quality of river Ganga in Haridwar District Rasayan Journel of Chemistry 2:285-292.

Doneen, L.D., (1962). The influence of crop and soil on percolating water. In: Proceedings of the 1961 biennial conference on ground water recharge, 156-163.

Doul, J., Klassen, C. and Amdur, M. (1980). Casaret and Doul's Toxicology, 2nd ed., 239-245. NY: Macmillan.

Environment, S.A.O.F. s. (1995). Florida stream water quality index, statewide summary.

Garg, S., and Bahl, G.S. (2008). Phosphorus availability to maize as influenced by organic manures and fertilizer $\mathrm{P}$ associated phosphatase activity in soils. Bioresource Technology, 99: 5773-5777, DOI:https:// doi.org/10.1016/j.biortech.2007.10.063.

Gholami, S. and Srikantaswamy, S. (2009). Analysis of agricultural impact on the Cauvery River water around KRS Dam. World Applied Science Journal 6: 11571169

Gunatilake, S., Samaratunga, S. and Rubasinghe, R. (2015). Chronic Kidney Disease (CKD) in Sri LankaCurrent Research Evidence Justification: A Review. Sabaragamuwa University Journal 13: 31-58.

Gupta, S. K, and Gupta, I. C. (1987). Management of saline soils and water. Oxford and IBM Published Country, New Delhi, India.

Harshan, S., Thushyanthy, M., Gunatilake, J., Srivaratharasan, T. and Gunaalan, K. (2017). Assessment of water quality index of groundwater quality in Chunnakam and Jaffna Town, Sri Lanka. Vingnanam Journal of Science. 13: 84-91.

Horton, R.K. (1965). An index number system for rating water quality. Journal of Water Pollution Control Federation. 37: 300-306.

Ileperuma, O., Dharmagunawardhane, H. and Herath, K. (2009). Dissolution of aluminium from sub-standard utensils under high fluoride stress: a possible risk factor for chronic renal failure in the North-Central Province. Journal of the National Science Foundation of Sri Lanka. 37: 219-222.

Jessani, S., Levey, A.S., Bux, R., Inker, L.A., Islam, M., Chaturvedi, N., Mariat, C., Schmid, C. H. and Jafar, T. H. (2014). Estimation of GFR in South Asians: a study 
from the general population in Pakistan. American journal of kidney diseases. 63: 49-58, DOI : https://doi. org/10.1053/j.ajkd.2013.07.023.

Kausar, S., Asghar, K., Anwar, S.M., Shaukat, F. and Kausar, R. (2011). Factors affecting drinking water quality and human health at household level in Punjab, Pakistan. Pakistan Journal of Life and Social Sciences 9:33-37.

Kelly, W.P. (1963). Use of saline irrigation water. Soil Science 95:355-359.

Khan, A. A., Paterson, R. and Khan, H. (2004). Modification and Application of the Canadian Council of Ministers of the Environment Water Quality Index(CCME WQI) for the Communication of Drinking Water Quality Data in Newfoundland and Labrador. Water Quality Research Journal of Canada. 39: 285-293, DOI:https:// doi.org/10.2166/wqrj.2004.039.

Khan, T.A. and Abbasi, M.A. (2013). Synthesis of parameters used to check the suitability of water for irrigation purposes. International Journal of Environmental Science, 3:2031-2038, DOI : 10.6088/ ijes. 2013030600029.

Khodapanah, L., Sulaiman, W.N.A. and Khodapanah, N. (2009). Groundwater quality assessment for different purposes in Eshtehard District, Tehran, Iran. European Journal of Scientific Research, 36:543-553.

Lin, B., Shao, L., Luo, Q., Ou-yang, L., Zhou, F., Du, B., $\mathrm{He}, \mathrm{Q} ., \mathrm{Wu}, \mathrm{J} ., \mathrm{Xu}, \mathrm{N}$. and Chen, J. (2014). Prevalence of chronic kidney disease and its association with metabolic diseases: a cross-sectional survey in Zhejiang province, Eastern China. BMC nephrology. 15, p36 DOI: $10.1186 / 1471-2369-15-36$.

Madhushakha, L., Dhammika, M., Charitha, P., Tilak, A. and Lishantha, G. (2016). Cyanobacteria and cyanotoxins in well waters of the girandurukotte, ckdu endemic area in Sri Lanka; do they drink safe water? Journal of Ecotechnology Research. 18: 17-21, DOI: https://doi.org/10.11190/jer.18.17.

Maher, J. (1976). Toxic nephropathy. The kidney. 2: 13551395.

Milovanovic, M. (2007). Water quality assessment and determination of pollution sources along the Axios/ Vardar River, Southeastern Europe. Desalination, 213: 159-173, DOI: https://doi.org/10.1016/j. desal.2006.06.022.

Mishra, R., Kotasthane, S., Khare, M., Gupta, O. and Tiwari, S. (1985). Reaction of lentil varieties and exotic germplasm to rust (Uromyces fabae). Lentil Experimental News Service.

Mohan, S. V., Mohan, S. K. and Reddy, S. J. (2000). Determination of organic matter in water using organometal complexes. Water research, 34: 3761-3764, DOI: https://doi.org/10.1016/S0043-1354(00)00124-X.

Nagaraju, A., Suresh, S., Killham, K., and HudsonEdwards, K. (2006). Hydrogeochemistry of waters of mangampeta barite mining area, Cuddapah Basin, Andhra Pradesh, India. Turkish Journal of Engineering and Environmental Sciences, 30: 203-219.

Ogunfowokan, A.O., Ogunkoya, O.O. and Obisanya, J.F. (2013). Salinity and sodium hazards of

three streams of different agricultural land use systems in
Ile-Ife, Nigeria. Applied Water Science ,3:19-28, DOI: https://doi.org/10.1007/s13201-012-0053-2.

Rahmanian, N., Ali, S.H.B., Homayoonfard, M., Ali, N.J., Rehan, M., Sadef, Y. and Nizami, A.S. (2015). Analysis of physiochemical parameters to evaluate the drinking water quality in the State of Perak, Malaysia. Journal of Chemistry, 1-10, Article ID 716125, DOI: https://doi. org/10.1155/2015/716125.

Raihan, F. and Alam, J.B. (2008). Assessment of groundwater quality in Sunamganj of Bangladesh. Iranian Journal of Environmental Health Science and Engineering 5:155-166.

Ramachandran, S. (1994). Renal diseases: Sri Lankan and global spectrum. Journal of Ceylon Coll Physicians. 27: 27-35.

Reddad, Z., Gerente, C., Andres, Y. and Le Cloirec, P. (2002). Adsorption of several metal ions onto a lowcost biosorbent: kinetic and equilibrium studies. Environmental science \& technology. 36: 2067-2073, DOI:https://doi.org/10.1021/es0102989.

Richards, L.A. (1969). Diagnosis and improvement of saline and alkali soils, United States Department Of Agriculture; Washington.

Rubasinghe, R., Gunatilake, S. and Chandrajith, R. (2015). Geochemical characteristics of groundwater in different climatic zones of Sri Lanka. Environmental Earth Sciences. 74: 3067-3076, DOI: https://doi. org/10.1007/s12665-015-4339-1.

Singh, V. and Singh, U.C. (2008). Assessment of groundwater quality of parts of Gwalior (India) for agricultural purposes. Indian Journal of Science and Technology 1:1-5.

Saldanha, L.F., Rosen, V.J. and Gonick, H.C. (1975). Silicon nephropathy. The American journal of medicine. 59: 95-103, DOI: https://doi.org/10.1016/00029343(75)90326-5.

Siriwardhana, E., Perera, P., Sivakanesan, R., Abeysekara, T., Nugegoda, D. and Jayaweera, J. (2015). Dehydration and malaria augment the risk of developing chronic kidney disease in Sri Lanka. Indian Journal of Nephrology. 25: p146, DOI: 10.4103/09714065.140712.

Stefanović, V. (1999). Balkan endemic nephropathy: A reappraisal after forty years. Facta universitatis-series: Medicine and Biology. 6: 53-58.

Todd, D. (1980). Groundwater hydrology, p. 535, Jon Wiley \& Sons, New York.

Trivedy, R.K., and Goel, P.K. (1986). Chemical and Biological methods for water pollution studies, environmental publication, Karad. Maharashtra and India.

Wanigasuriya, K. (2012). Aetiological factors of Chronic Kidney Disease in the North Central Province of Sri Lanka: A review of evidence to-date, 17:15-20.

Wanigasuriya, K. P., Peiris, H., Ileperuma, N., Peiris-John, R. J. and Wickremasinghe, R. (2008). Could ochratoxin $\mathrm{A}$ in food commodities be the cause of chronic kidney disease in Sri Lanka? Transactions of the Royal Society of Tropical Medicine and Hygiene. 102: 726-728, DOI: https://doi.org/10.1016/j.trstmh.2008.04.007.

Weaver, V. M., Fadrowski, J. J. and Jaar, B.G. (2015). Global 
dimensions of chronic kidney disease of unknown etiology $(\mathrm{CKDu})$ : a modern era environmental and/or occupational nephropathy? BMC nephrology. 16: p145.

WHO, J. and Organization, W.H. (2003). Diet, nutrition and the prevention of chronic diseases: report of a joint WH.

Wimalawansa, S.J. (2016). The role of ions, heavy metals, fluoride, and agrochemicals: critical evaluation of potential aetiological factors of chronic kidney disease of multifactorial origin (CKDmfo/CKDu) and recommendations for its eradication. Environmental geochemistry and health. 38: 639-678.

Zandbergen, P.A. and Hall, K.J. (1998). Analysis of the British Columbia water quality index for watershed managers: a case study of two small watersheds. Water Quality Research Journal of Canada. 33:DOI: https:// doi.org/10.2166/wqrj.1998.030 